каждого источника сбросов радиоактивных веществ требуется определить какими радионуклидами из перечня формируются 99\% годовой активности населения. МАГАТЭ рекомендует рассматривать 31 радионуклид в качестве стрессоров для оценки воздействия на окружающую среду от сбросов АЭС [1].

Состав сбросов АЭС с реакторными установками на тепловых нейтронах AGR, BWR, LWGR, PWR и CANDU может быть получен из анализа информации по контролю сбросов в Европе, за исключением реакторов на быстрых нейтронах. Так как данные типы реакторов широко распространены в мире, то мы можем обобщить полученные данные для Европы на мировую практику. Основную активность сбросов (не менее 99\%) активности формируют ${ }^{14} \mathrm{C},{ }^{3} \mathrm{H},{ }^{137} \mathrm{Cs}$ и ${ }^{90} \mathrm{Sr}$ для данных атомных станций. Полученные результаты не противоречат рекомендациям МАГАТЭ и ранее полученным данным [2].

1. International Atomic Energy Agency. Nuclear Energy Series. No. NG-T-3.15. Vienna: IAEA, 98 p. (2016).

2. А.А.Екидин, Г.П.Малиновский и др., Атомная энергия, Т. 119. № 4, 219-221 (2015).

\title{
THE INNOVATIVE APPROACH TOWARDS IMPROVING GREEN BIOTECHNOLOGY IN NIGERIA
}

\author{
Bulya T.E. ${ }^{{ }^{*}}$, Javed F. ${ }^{1}$, Ivantsova M.N. ${ }^{1}$ \\ ${ }^{1)}$ Institute of Chemical Engineering, Ural Federal University, Yekaterinburg, Russia \\ *E-mail: nuellabulya@gmail.com
}

Abstract. We have discussed the innovative approach towards green biotechnology in Nigeria, the efforts that have been put in making green biotechnology see the light of the day in Nigeria, the public view about green biotechnological products and the challenges faced in Nigeria in implementing the technological innovation.

Due to the rapid growth of Biotechnology in the globe, Nigeria officially signed the bio safety bill into law in 2015, making it eligible to join the nations that are already using biotechnology and genetic modification. National Biotechnology Development Agency Nigeria related this biotechnology to genetic engineering which in turn would boosts food production and alleviate hunger [1].

Biotechnology as defined by UN Convention is any technological application that uses biological systems, living organisms or any derivatives thereof, to modify/make products or processes for specific use [2]. The Biotechnological novel creates room for various disciplines such as physics, chemistry and biology which allow the designing of different biological systems that differ in degree of complexity and organisation, resulting to wide range of macromolecules. 
Colours play crucial role in communication and every colour has its significance in the world of communication representing thoughts, actions and reaction. Biotechnology and the colour world have always worked handy since the beginning of raising awareness for the various fields of biotechnology. Some scientists described the life science aspect of biotechnology as a rainbow with each sector having its own colour code [3]. Biotechnology is symbolized majorly by four colours. Red biotechnology is for the health and medical sector including diseases and diagnostics. Green biotechnology represents agriculture or food, plant and environment. White or Grey biotechnology represents the industrial sector, and Blue biotechnology is for aquaculture and marine.

Nigeria is working towards creating a solid foundation for this new technology and the Federal Government with the passage of the bio-safety bill into law in line with the world standard has approved the establishment of a national regulatory body and the National Bio-safety Management Agency (NBMA) to oversee the safe application of biotechnology in the country [4]. In this paper we intend to discuss the innovative approach towards green biotechnology in Nigeria, the efforts that have been put in making green biotechnology see the light of the day in Nigeria, the public view about green biotechnological products and the challenges faced in Nigeria in implementing the technological innovation. Agricultural products were the main foreign exchange earner for Nigeria years ago [5].

Agricultural practice in Nigeria is common, majorly as a result of the soil fertility and the introduction of Biotechnology in country has created a new phase for agriculture. The nation is on track to commercialize genetically engineered cowpea and cotton this year. Both crops contain the Bt gene to confer pest resistance.

1. Nkechi Isaac, Nigeria has two GMO crops on track for 2018, Cornell Alliance for Science (2018).

2. UN Convention on Biological Diversity, Art 2 (2013).

3. Edgar J. Dasilva, The Colours of Biotechnology: Science, Development and Humankind Paris, France (2012).

4. Abdullah el-Kurebe, How biotechnology can optimize agriculture in Nigeria National Biotechnology Development Agency (2017).

5. Ake C., Democracy and Development in Africa. Brookings Institution Press, Washington, DC, p. 48 (1996). 